\title{
Taxonomy of the genus Keetia (Rubiaceae-subfam. Ixoroideae-tribe Vanguerieae) in southern Africa, with notes on bacterial symbiosis as well as the structure of colleters and the 'stylar head' complex
}

\author{
P.M. TILNEY* and A.E. VAN WYK**
}

Keywords: Afrocanthium (Bridson) Lantz \& B.Bremer, anatomy, bacteria, Canthium Lam., colleters, Keetia E.Phillips, Psydrax Gaertn., Rubiaceae, taxonomy, Vanguerieae

ABSTRACT

The genus Keetia E.Phillips has a single representative in the Flora of southern Africa region (FSA), namely K. gueinzii (Sond.) Bridson. The genus and this species are discussed, the distribution mapped and traditional uses indicated. The structures of the calycine colleters, and the 'stylar head' complex which is involved in secondary pollen presentation, are elucidated and compared with existing descriptions. Intercellular, non-nodulating, slime-producing bacteria are reported in leaves of a Keetia for the first time. Differences between the southern African representatives of Keetia, Psydrax Gaertn, Afrocanthium (Bridson) Lantz \& B.Bremer, and Canthium s. str., which for many years were included in Canthium s.l., are given.

\section{INTRODUCTION}

This paper is the first in a planned series on the classification of the Canthium s.l. group of the tribe Vanguerieae in southern Africa. This tribe of the Rubiaceae is notorious for the difficulties in resolving generic boundaries. For most of the 20th century the name Canthium Lam. was applied in a broad generic sense to a heterogeneous assemblage of taxa in southern Africa (Phillips 1951; Dyer 1975). Pioneering work initiated by Bridson (1985) was followed by several subsequent contributions advocating the recognition of various segregate genera. Evidence in support of the subdivision of Canthium s.l. has been forthcoming, amongst others, from anatomy and morphology (Tilney 1986), palynology (Tilney \& Van Wyk 1997) as well as comparative molecular studies (Lantz \& Bremer 2004). In this contribution we briefly review the generic treatment of Canthium s.l., followed by a taxonomic treatment of the genus Keetia E.Phillips for the Flora of southern Africa (FSA) region. Notes are also provided on the morphology and anatomy of the calycine colleters and 'stylar head' complex in K. gueinzii, as well as a first report on slime-producing bacteria in the leaves.

\section{MATERIAL AND METHODS}

Leaves, flowers in various stages of maturity, and fruits were selected for study (see below for voucher specimens). Fresh material was preserved in FAA; dried material was first rehydrated in distilled water and then placed in FAA. Transverse sections of fruits and lamina portions (of healthy leaves including portions with domatia, and of gall-infected leaves), as well as transverse and longitudinal sections of flowers, were prepared by embedding in GMA, sectioning with an ultramicrotome and staining according to the periodic acid/Schiff reaction, with tolui-

\footnotetext{
* Department of Botany and Plant Biotechnology, University of Johannesburg, P.O. Box 524, 2006 Auckland Park, Johannesburg.

** H.G.W.J. Schweickerdt Herbarium, Department of Plant Science, University of Pretoria, 0002 Pretoria.

MS. received: 2008-10-16.
}

dine blue as counterstain (Feder \& O’Brien 1968). Slides are housed at JRAU. For scanning electron microscopy, material was examined with a Jeol JSM 5600 scanning electron microscope after being coated with gold. Some sections of the 'stylar head' complex were treated with Sudan black and Sudan III to reveal any cutinization.

Voucher specimens (acronyms of herbaria as in Holmgren et al. 1990) are as follows:

Leaves: (lamina structure in t/s): Abbott 70 (PRU), Compton 3155 (PRE), Hafström \& Acocks 1929 (PRE), Kok 712 (PRU), Van Wyk \& Kok 5888 (PRU); (domatia): Thompson s.n. (JRAU), Tilney 267 (JRAU); (galls): Tilney 266 (JRAU); (stipules): Tilney 156, 267 (JRAU).

Flowers: (light microscopy): Burrows 9558 (BNRH+), Thompson s.n. (JRAU), Tilney 162, 267 (JRAU); (scanning electron microscopy): Thompson s.n. (JRAU).

Fruits: Abbott 70 (PRE), Hemm 45A (PRU), Kluge 25 (PRU), Kok 712 (PRU), Van Wyk 2702 (PRU), Van Wyk \& Theron 4568 (PRU).

\section{GENERIC CONCEPTS}

The tribe Vanguerieae consists of about 600 species largely restricted to sub-Saharan Africa and Madagascar, but some are also found in southern Asia, the Pacific Ocean islands and Australia. Amongst the principal characters shared by members of the Vanguerieae are axillary inflorescences, flowers with corolla lobes valvate and thickened, stamens inserted on the rim of the corolla tube, single pendulous ovules in each locule of the ovary and fruit a drupe with one or more pyrenes. Most notable, however, are the anthers in the bud which are in close contact with a modified portion of the upper style, a so-called 'stylar head' complex (Igersheim 1993), where the pollen is deposited and which serves in secondary pollen presentation.

Canthium and Vangueria Comm. ex Juss. are among the oldest generic names in the Vanguerieae as currently delimited. The former is partly defined by having two

\footnotetext{
+ temporary acronym: Buffelskloof Nature Reserve Herbarium, Lydenburg.
} 
locules and the latter five (Lantz et al. 2002). According to Bridson (1985), Canthium s.l. was a very heterogeneous group of species and she re-instated the genera Psydrax Gaertn. and Keetia (Bridson 1986) to accommodate several of the members. The distinctiveness of the leaf and young stem anatomy, pollen morphology and fruit structure of Keetia gueinzii (Sond.) Bridson from other southern African species of Canthium s.l. was shown by Tilney (1986). Using sequence data from the Internal Transcribed Spacer (ITS) region in the nuclear ribosomal DNA, Lantz et al. (2002) confirmed the separate generic status of Keetia. Their study also provided evidence that Keetia is one of the best-delimited genera in the Vanguerieae. In further studies, Lantz \& Bremer (2004) added trnT-F sequences from the chloroplast genome and morphological characters. Keetia was again shown to be monophyletic with strong support. Morphologically, Keetia species are climbers or scandent shrubs, rarely small trees, have a lidlike area on the pyrenes and, at least in the species examined, smooth retrorse hairs in the corolla tube.

The genus Psydrax is weakly supported as monophyletic in a molecular study (Lantz \& Bremer 2004), but the species share a number of morphological (Lantz \& Bremer 2004) and anatomical (Tilney 1986) synapomorphies. Psydrax, the most widely distributed genus of the tribe, is thought to be related to Keetia (Bridson 1985, 1986). The southern African representatives of

TABLE 1.-Distinguishing characters in southern African species of Keetia, Afrocanthium, Canthium s. str. and Psydrax

\begin{tabular}{|c|c|c|c|c|}
\hline Characters & Keetia (K. gueinzii) & $\begin{array}{l}\text { Afrocanthium (A. gilfillanii, } \\
\text { A. mundianum) }\end{array}$ & $\begin{array}{l}\text { Canthium s. str. (C. ciliatum, } \\
\text { C. inerme, C. kuntzeanum, C. } \\
\text { spinosum, C. suberosum, C. } \\
\text { vanwykii) }\end{array}$ & $\begin{array}{l}\text { Psydrax }(P \text {. fragrantissima, } P . \\
\text { locuples, } P \text {. livida, } P \text {. obovata })\end{array}$ \\
\hline Habitat & On forest margins & $\begin{array}{l}\text { On rocky ridges, may also } \\
\text { occur in forest; often in small } \\
\text { groups }\end{array}$ & $\begin{array}{l}\text { Variety of habitats although } \\
\text { individual species may have } \\
\text { restricted distribution }\end{array}$ & $\begin{array}{l}\text { In bushveld or other regions } \\
\text { with some individual species } \\
\text { having a restricted distribution }\end{array}$ \\
\hline Growth form & $\begin{array}{l}\text { Robust climber or scrambling } \\
\text { shrub }\end{array}$ & Tree or shrub & Tree or shrub & Tree or shrub \\
\hline Duration & Evergreen & Usually deciduous & Usually deciduous & Usually evergreen \\
\hline Spines & Absent & Absent & $\begin{array}{l}\text { Present but may be mainly } \\
\text { associated with coppice } \\
\text { growth }\end{array}$ & Absent \\
\hline Young plant parts & $\begin{array}{l}\text { Covered in ginger-brown } \\
\text { hairs }\end{array}$ & With whitish hairs & Glabrous & Glabrous or with whitish hairs \\
\hline Side branches & $\begin{array}{l}\text { Often subtended by smaller } \\
\text { rotund leaves }\end{array}$ & $\begin{array}{l}\text { Not subtended by smaller } \\
\text { rotund leaves }\end{array}$ & $\begin{array}{l}\text { Not subtended by smaller } \\
\text { rotund leaves }\end{array}$ & $\begin{array}{l}\text { Not subtended by smaller } \\
\text { rotund leaves }\end{array}$ \\
\hline \multicolumn{5}{|l|}{ Leaves } \\
\hline length of blade & $\begin{array}{l}\text { At least } 70 \mathrm{~mm} \text { but usually } \\
\text { considerably more }\end{array}$ & $\begin{array}{l}\text { Considerably less than } 70 \\
\mathrm{~mm}\end{array}$ & $\begin{array}{l}\text { Considerably less than } 70 \\
\mathrm{~mm}\end{array}$ & Considerably less than $70 \mathrm{~mm}$ \\
\hline texture & Thinly textured, \pm leathery & Soft and easily wilting & $\begin{array}{l}\text { Generally soft and easily wilt- } \\
\text { ing, rarely stiff and leathery }\end{array}$ & Generally stiff and leathery \\
\hline base & Usually subcordate to cordate & Frequently tapering & Frequently tapering & Frequently tapering \\
\hline stipules & $\begin{array}{l}\text { Not keeled; without hair tufts } \\
\text { inside }\end{array}$ & $\begin{array}{l}\text { Usually slightly keeled; } \\
\text { without hair tufts inside }\end{array}$ & $\begin{array}{l}\text { Usually not keeled, occasion- } \\
\text { ally slightly so; hair tufts } \\
\text { present inside }\end{array}$ & $\begin{array}{l}\text { Keeled, usually strongly so; } \\
\text { without hair tufts inside }\end{array}$ \\
\hline Domatia & Tufts & Tufts & $\begin{array}{l}\text { Tufts, or pits sometimes with } \\
\text { small hairs }\end{array}$ & $\begin{array}{l}\text { Pits, pockets or domes with } \\
\text { opening at top, sometimes } \\
\text { with hairs }\end{array}$ \\
\hline Flowers & $\begin{array}{l}\text { In dense shortly-pedunculate } \\
\text { clusters in leaf axils }\end{array}$ & $\begin{array}{l}\text { Usually in small shortly- } \\
\text { pedunculate clusters, rarely } \\
\text { in dense clusters in leaf axils }\end{array}$ & $\begin{array}{l}\text { Solitary or in small shortly- } \\
\text { pedunculate clusters, occa- } \\
\text { sionally in dense clusters in } \\
\text { leaf axils }\end{array}$ & $\begin{array}{l}\text { Usually in small shortly- } \\
\text { pedunculate clusters, occa- } \\
\text { sionally in dense clusters in } \\
\text { leaf axils }\end{array}$ \\
\hline Anthers & $\begin{array}{l}\text { Fully exserted but rarely } \\
\text { reflexed }\end{array}$ & $\begin{array}{l}\text { Partially to fully exserted but } \\
\text { never reflexed }\end{array}$ & $\begin{array}{l}\text { Often only partially exserted } \\
\text { and not reflexed }\end{array}$ & Exserted and usually reflexed \\
\hline \multicolumn{5}{|c|}{ 然 } \\
\hline length & $\begin{array}{l}\text { At least twice length of } \\
\text { corolla tube }\end{array}$ & $\begin{array}{l}\text { Slightly longer than corolla } \\
\text { tube }\end{array}$ & $\begin{array}{l}\text { Usually somewhat longer } \\
\text { than corolla tube (in C. kuntz- } \\
\text { eanum } \pm \text { as long) }\end{array}$ & $\begin{array}{l}\text { Usually much longer than } \\
\text { corolla tube }\end{array}$ \\
\hline head & Distinctly longer than wide & Usually \pm as long as wide & Usually wider than long & Usually longer than wide \\
\hline \multicolumn{5}{|l|}{ Fruit } \\
\hline shape & Globose & $\begin{array}{l} \pm \text { globose, but reniform when } \\
\text { single-seeded }\end{array}$ & Usually somewhat elongated & \pm globose \\
\hline size & Relatively large & Relatively small & $\begin{array}{l}\text { Varies from relatively small } \\
\text { to relatively large }\end{array}$ & Relatively small \\
\hline pyrene & $\begin{array}{l}\text { With clear lid-like area } \\
\text { across apex }\end{array}$ & $\begin{array}{l}\text { Without clear lid-like area } \\
\text { across apex }\end{array}$ & $\begin{array}{l}\text { Without clear lid-like area } \\
\text { across apex }\end{array}$ & $\begin{array}{l}\text { Without clear lid-like area } \\
\text { across apex }\end{array}$ \\
\hline apical indentation & $\begin{array}{l}\text { 2-seeded fruit strongly or } \\
\text { slightly indented }\end{array}$ & $\begin{array}{l}\text { 2-seeded fruit not or scarcely } \\
\text { indented }\end{array}$ & $\begin{array}{l}\text { 2-seeded fruit strongly or } \\
\text { slightly indented }\end{array}$ & $\begin{array}{l}\text { 2-seeded fruit not or scarcely } \\
\text { indented }\end{array}$ \\
\hline Seed: endosperm & $\begin{array}{l}\text { Streaked with resinous } \\
\text { granules }\end{array}$ & $\begin{array}{l}\text { Not streaked with resinous } \\
\text { granules }\end{array}$ & $\begin{array}{l}\text { Not streaked with resinous } \\
\text { granules }\end{array}$ & $\begin{array}{l}\text { Not streaked with resinous } \\
\text { granules }\end{array}$ \\
\hline
\end{tabular}


Psydrax and other taxa, at one time called 'Canthium', will be discussed in future contributions. The genera Psydrax and Keetia are compared in Table 1.

Bridson (1987) divided the African Canthium species into four subgenera, one of which is Canthium subgenus Afrocanthium Bridson (Bridson 1987, 1992). The molecular studies of Lantz \& Bremer (2004) also support Canthium subgenus Afrocanthium as being monophyletic and this subgenus was therefore given generic rank. Although Keetia and Afrocanthium (Bridson) Lantz \& B.Bremer were strongly supported as sister taxa in these studies, the authors point out that the morphology gives little indication of this relationship - apart from a lack of white silky hairs inside the stipules of both $K$. gueinzii and Afrocanthium mundianum (Lantz \& Bremer 2004: 274), but this character is shared with many other Vanguerieae genera (Bridson 1998). In characterizing Afrocanthium, Lantz \& Bremer (2004) point out that it is geographically restricted to eastern and southern Africa (see Bridson 1992, Map 3). As a genus, Afrocanthium is further distinguished by the absence of a dark connective on the stamens, inflorescences borne at nodes from which the leaves have fallen, lenticels usually visible, and very short calyx limb tubes (Lantz \& Bremer 2004). A comparison between southern African species of Afrocanthium and Keetia incorporating other characters is given in Table 1.

The elevation of Canthium subgenus Afrocanthium to generic level as Afrocanthium has assisted in lessening the heterogeneity of the remaining Canthium s.l. species, at least in southern Africa, but the latter still remains polyphyletic (Lantz \& Bremer 2004). These researchers suggested that the genus Canthium s. str. should essentially be restricted to thorny members, i.e. those having paired, usually supra-axillary thorns. Also included in their concept of Canthium s. str. is the genus Plectroniella Robyns, a segregate based on the southern African $P$. armata (K.Schum.) Robyns, a species with the ovary plurilocular (the other taxa are bilocular). Since thorns are erratically present in some southern African members of the group, e.g. C. inerme (L.f.) Kuntze and C. suberosum Codd, this diagnostic character is more accurately expressed as having the potential to produce thorns. In the last-mentioned two species, thorns are either absent in some plants, or produced in juvenile plants or sucker shoots only. This is the sense in which Canthium s. str. has been used in Table 1. Note, however, that these spiny southern African species were kept as Canthium s.l. by Bridson (1992), as in her opinion they did not fully accord with the type of Canthium, namely C. coromandelicum (Burm.f.) Alston, from India.

\section{TAXONOMIC TREATMENT}

Keetia E.Phillips in Memoirs of the Botanical Survey of South Africa No. 10: 587 (1926); E.Phillips: 369 (1927); Bridson: 967 (1986); Bridson: 362 (1998); Retief \& Leistner: 487 (2000). Type: $K$. transvaalensis E.Phillips, now included in K. gueinzii (Sond.) Bridson.

Canthium sensu Sond.: 16 (1865) p.p., non Lam.; Hiern: 132 (1877) p.p.; Bullock: 360 (1932) p.p.; Phillips: 732 (1951) p.p.; Hepper: 180 (1963) p.p.; Dyer: 618 (1975) p.p.

Plectronia sensu auctt. div., non L.
The generic description below is for the genus as a whole and is largely based on Bridson $(1986,1998)$.

Climbers or scrambling shrubs, rarely small trees, evergreen; stems glabrous or frequently pubescent. Leaves not confined to new growth at ends of branchlets, petiolate, opposite, simple, margin entire; lamina chartaceous or occasionally coriaceous; those leaves subtending lateral branchlets often smaller and broader than main ones; stipules interpetiolar, lanceolate to ovate or triangular at base, not keeled, usually without white silky hairs inside. Inflorescences axillary, pedunculate and usually distinctly branched cymes; bracts and bracteoles often conspicuous. Flowers bisexual, 4-6merous. Calyx with segments \pm equal to or sometimes longer than tube. Corolla whitish or yellow, cylindrical, tube with a ring of deflexed hairs, throat often pubescent or bearded, lobes usually \pm same length as tube, curving well backwards, often thickened towards apex. Stamens 5 , attached in corolla throat; filaments moderately well developed; anthers partly or fully exserted, usually not reflexed, narrowly ovate or oblong. Disc nearly always puberulous to pubescent. Ovary 2-locular, with single ovule per locule, attached above middle of septum; style slender, \pm twice length of corolla tube; stigmatic knob ('stylar head'complex) cylindrical, conspicuously longer than wide, hollow to mid-point or to just below apex, apex slightly bifid at maturity. Fruit a 2-seeded drupe or often 1-seeded by abortion and asymmetric, slightly to strongly 2-lobed, somewhat laterally flattened, variously indented at apex, dark when mature; pyrenes woody or less often cartilaginous, usually \pm ovoid with ventral face flattened, somewhat colliculose, point of attachment either on ventral face shortly above centre or near apex; lid-like area completely or incompletely defined (but more clearly apparent from inside), either lying along ventral face above point of attachment, or across apex, provided with a central crest, presumably dehiscent around circumference on germination. Seed ovoid, shaped at apex according to position of lid-like area in pyrene, convoluted; endosperm streaked with patches of resinous granules (resembling a ruminate endosperm except that testa is never invaginated), or less often with resinous granules evenly dispersed or absent; testa thin, very finely reticulate; embryo straight with radicle erect, and small cotyledons lying parallel to ventral face of seed.

A genus of \pm 40 species, occurring in southern and throughout tropical Africa. Named after J.D.M. Keet (1882-1976), a South African forester and plant collector (Gunn \& Codd 1981). Represented by Keetia gueinzii in the FSA region, a species common and widespread in Africa. $K$. venosa (Oliv.) Bridson is the only other species in southern Africa; it has been reported from Zimbabwe and Mozambique.

Keetia gueinzii (Sond.) Bridson in Kew Bulletin 41: 970 (1986); Bridson: 911 (1992); Pooley: 478 (1993); Bridson: 363 (1998); Van Wyk \& Van Wyk: 280 (1997); Tilney: 37 (2002), 19 (2003a), 28 (2003b); Coates Palgrave: 1101 (2002); Schmidt et al.: 628 (2002). Type: South Africa, Port Natal, Gueinzius 576 (P sheet P00551153!, lecto., here designated; sheet P00551152!, iso.). 
Note: Gueinzius 71.576, as cited in Sonder (1850), is a typographical error; the full stop should be a comma, thus indicating two different gatherings. The other syntype, Gueinzius 71, could not be traced, unless this is the same as Gueinzius s.n. cited by Bridson (1986) as holotype, but considering the aforementioned comment, it should be a syntype.

Canthium gueinzii Sond. 54 (1850); Sond.: 16 (1865); Moore 40: 89 (1911); Bullock: t. 3170 (1932a); Bullock: 368 (1932b); Henkel: 147 (1934); Dale \& Greenway: 428 (1961); White: 403 (1962); Palmer \& Pitman: 2093 (1972); Compton: 580 (1976); Coates Palgrave: 881 (1977).

Plectronia gueinzii (Sond.) Sim: 241 (1907); Eyles: 493 (1916); Bews: 198 (1921).

\section{K. gueinzii Von Breitenbach: 91 (1985), nom. invalid.}

K. transvaalensis E.Phillips: 369 (1927), p.p., excluding syntypes Schlechter 12290 [PRE!; K. venosa (Oliv.) Bridson] and Borle 293 [PRE!; K. zanzibarica (Klotzsch) Bridson subsp. cornelioides (De Wild.) Bridson]. Type: South Africa, Transvaal, Barberton, woody ravines, Galpin 519 (K, lecto. !; PRE, iso.!).

Illustrations: Bullock: t. 3170 (1932a); Gibson: plate 102, 6 (1975); Bridson: 969, fruit (1986); Bridson: 358, fruit (1991); Pooley: 479 (1993); Van Wyk \& Van Wyk: 281 (1997); Bridson: 364 (1998); Schmidt et al.: 629 (2002).

Robust climber or scrambling shrub, rarely a small tree $\pm 3 \mathrm{~m}$ high; main stem faintly 4 -angled, becoming dark brown to almost black, smooth to finely rough; branches long and trailing, with slender branchlets almost at right angles and sometimes slightly bending backwards, sparsely to densely covered with fine, brownish hairs; unarmed. Leaves oblong-lanceolate to ovate, $40-135 \times 28-60 \mathrm{~mm}$ but those subtending lat- eral branches much smaller and often almost round, rather thinly textured, glossy dark green, usually drying brown, glabrous or very sparsely hairy adaxially, abaxially somewhat paler with sparse or dense rough hairs particularly on 6-9 pairs of lateral veins, with fine net-veining and hair-tuft domatia (Figure 1A, B); apex attenuate; base usually subcordate to cordate or sometimes rounded to truncate; margin slightly rolled under; petiole 3-13 mm long, hairy; stipules conspicuous, lanceolate to ovate, tapering to a point, $9-13 \mathrm{~mm}$ long, up to $6 \mathrm{~mm}$ wide at base, densely hairy on both surfaces but particularly on midrib where hairs longer and with tanniniferous substances when very young, becoming more sparsely hairy with most hairs confined to abaxial midrib when mature (Figure 2A, B), yellowish, falling early. Inflorescence in dense 20-50-flowered, branched axillary cymes; peduncle $5-15 \mathrm{~mm}$ long, at least initially pubescent; pedicels $3-7 \mathrm{~mm}$ long, pubescent to densely pubescent; bracteoles, linear-lanceolate to lanceolate, 3-6 mm long, hairy. Flowers usually produced in profusion, sweetly scented, 5-merous. Calyx with tube campanulate, 1-2 $\mathrm{mm}$ long, usually pilose below, glabrous above; calyx-limb obtuse, up to $\pm 1.5 \mathrm{~mm}$ long, divided into teeth for \pm half its length, usually sparsely pilose to glabrescent and ciliate at apex; colleters present on adaxial surface, usually between calyx lobes, singly or in pairs, \pm squashed (Figure $2 \mathrm{C}-\mathrm{E}$ ). Corolla white at anthesis, fading to cream-coloured or pale yellow; tube $2.2-5.0 \mathrm{~mm}$ long, gradually widening upwards, glabrous without, with erect hairs at throat and deflexed hairs
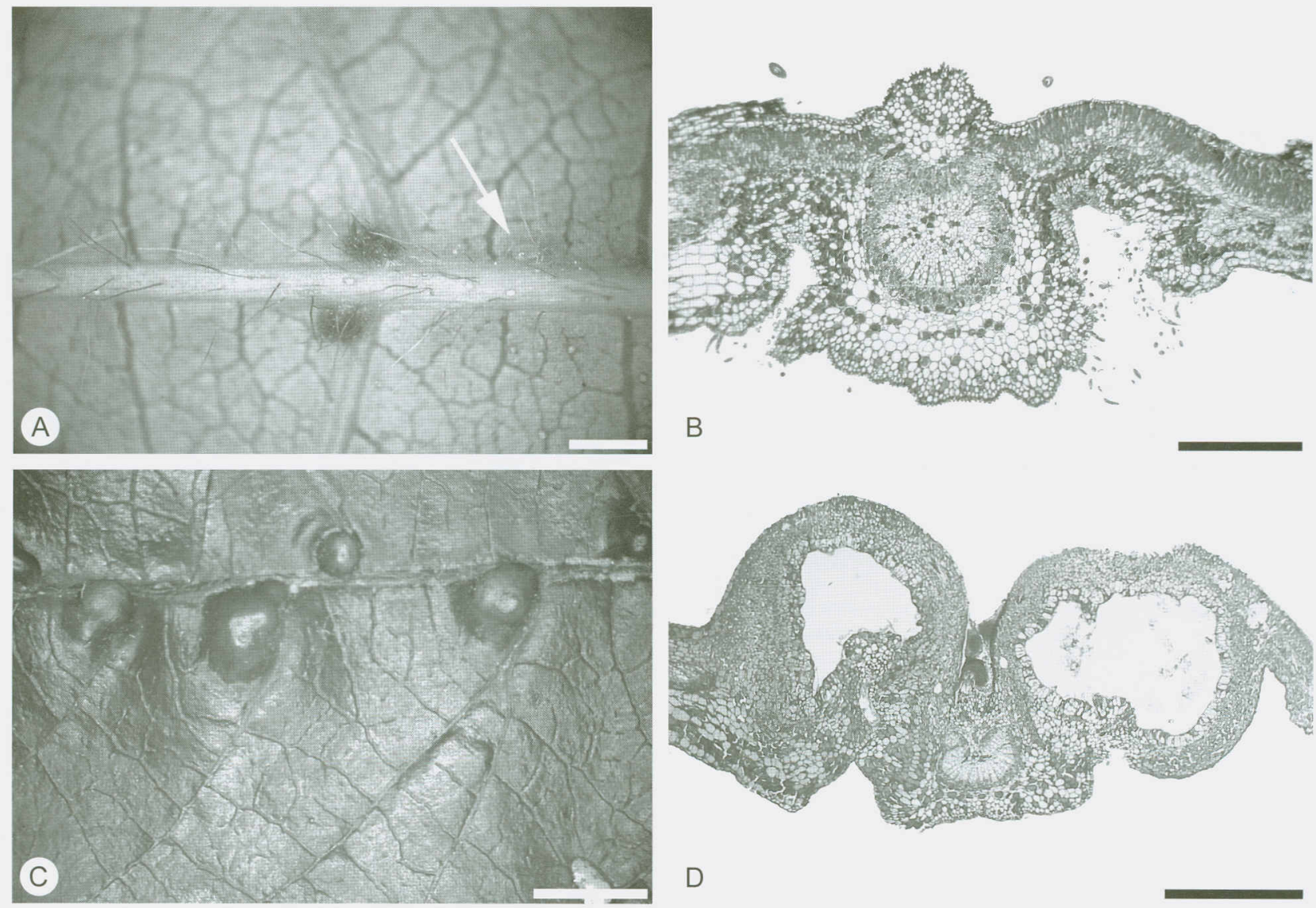

D

FIGURE 1.- Keetia gueinzii. A, hair-tuft domatia with a mite arrowed (Thompson s.n.); B, t/s of part of leaf showing domatia and vascular tissue of midrib in form of an arc with invaginated ends (Tilney 267). C, D, Tilney 266: C, portion of adaxial surface of leaf showing galls; D, t/s of midrib area and two galls. Scale bars: A, $1 \mathrm{~mm}$; B, $400 \mu \mathrm{m}$; C, 4 mm; D, $700 \mu \mathrm{m}$. 

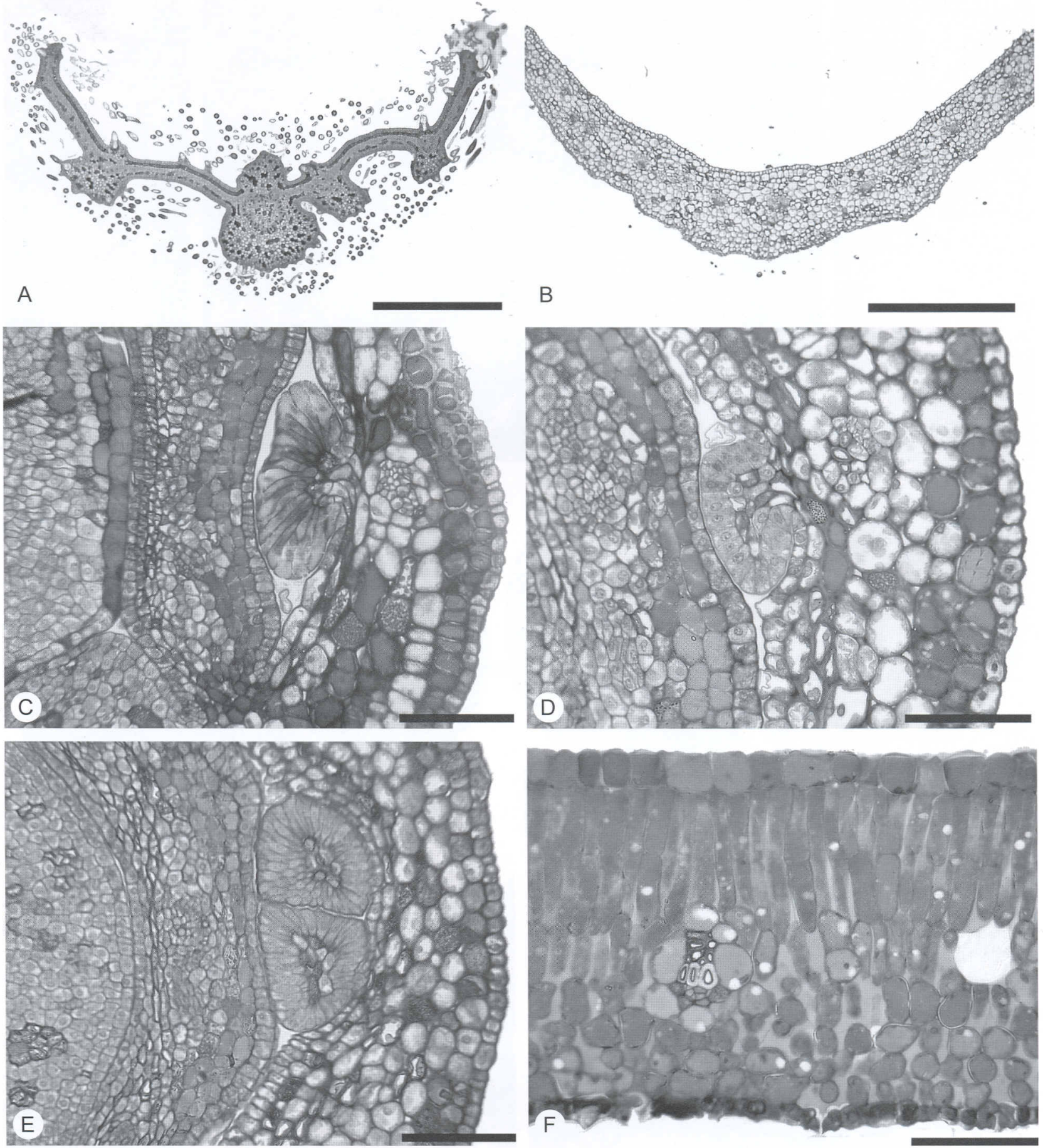

FIGURE 2.-Keetia gueinzii. A, t/s of very young stipule with abundant hairs on both surfaces (Tilney 156); B, t/s of portion of mature stipule showing sparse hairs mainly on abaxial surface (Tilney 267). C-E, Tilney 267: C, 1/s of portion of bud showing calycine colleter; D, colleters can clearly be seen to form as emergentia from sepals; $\mathrm{E}, \mathrm{t} / \mathrm{s}$ of portion of bud in which two calycine colleters are visible. $\mathrm{F}$, $\mathrm{t} / \mathrm{s}$ of portion of lamina with slime-producing bacteria filling most of intercellular spaces (Van Wyk \& Kok 5888). Scale bars: A, B, $700 \mu \mathrm{m}$; C-E, $100 \mu \mathrm{m} ; \mathrm{F}, 70 \mu \mathrm{m}$.

inside below throat; lobes spreading, oblong-lanceolate to ovate, $2.3-4 \times 1.2-2.3 \mathrm{~mm}$, apex acute and thickened. Stamens adnate to corolla throat; filaments erect, 1.5-2.0 mm long; anthers fully exserted, \pm erect, $3 \times 1$ $\mathrm{mm}$, brown and shriveled at anthesis. Disc plane, \pm 0.5 mm wide, pubescent. Ovary with style linear, gradually tapering upwards, 5-10 mm long, pale green, glabrous; pollen presenter pale green, covered with yellow pollen, $1.8-2.3 \times 1.5 \mathrm{~mm}$ (Figures 3A, C-F; 4). Fruit single or 2-lobed, broadly oblong to roundish, 9-14 × 7-14 mm, slightly indented, in dense, short-branched clusters, turn- ing blackish, nearly always pubescent when immature becoming glabrous or very rarely possessing few hairs largely restricted to base in vicinity of pedicel; pyrene with lid-like area across apex. Seed with cotyledons orientated parallel to ventral face of seed; endosperm with tanniniferous intrusions (Figure 5). Flowering time: September to November. Fruiting time: October to May.

Etymology: the specific epithet commemorates Wilhelm Gueinzius (1814-1874), a German apothecary and naturalist who lived in KwaZulu-Natal from 1841 until his death (Gunn \& Codd 1981; Hedge 1993). 

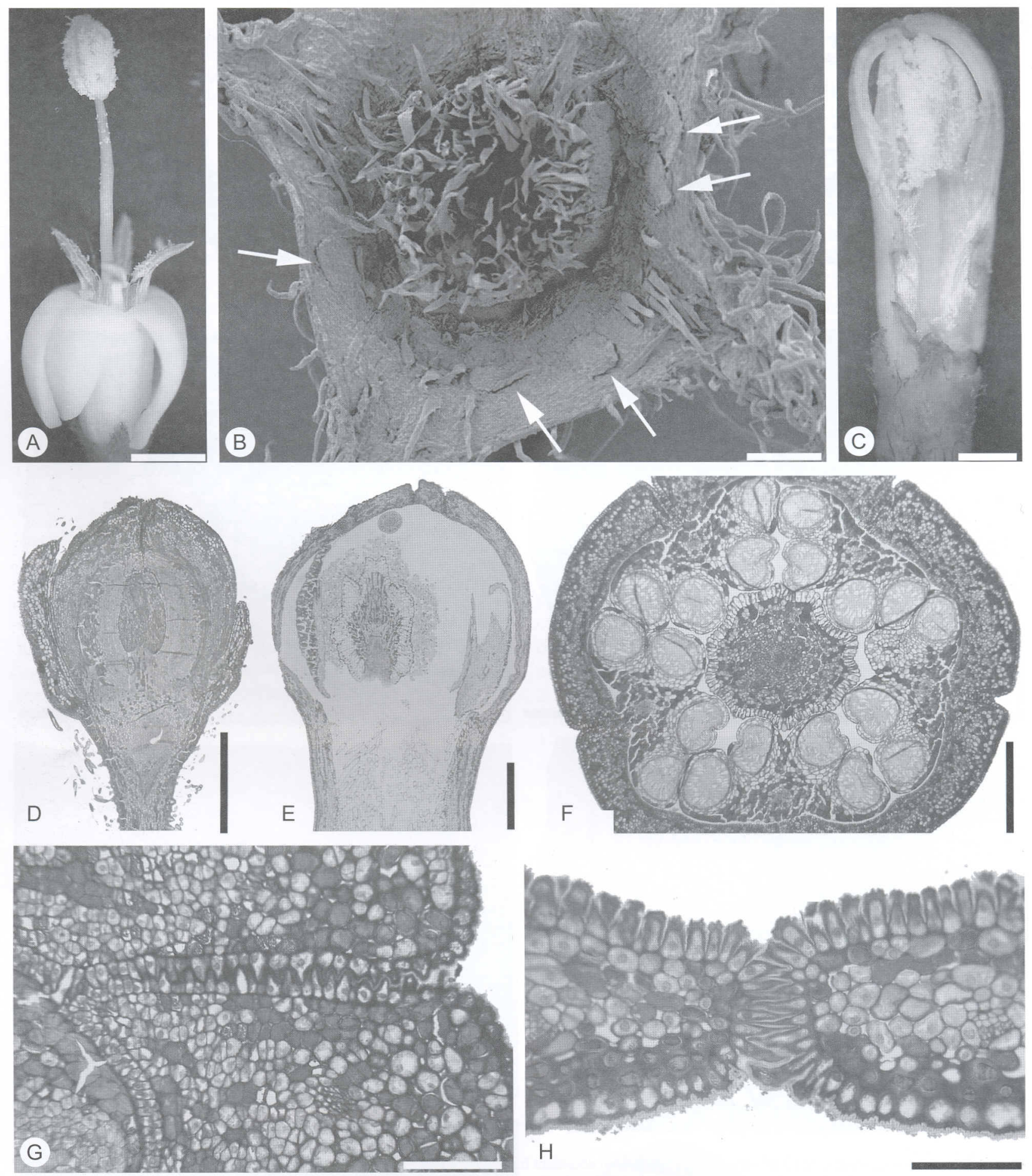

FIGURE 3.-Keetia gueinzii. A-C, Thompson s.n.: A, flower showing characteristic secondary pollen presentation and hairs concentrated on sepal lobes; B, SEM micrograph showing appearance and position (singly or in pairs) of calycine colleters (arrowed), and pubescent disc; C, young bud showing pollen already deposited on 'stylar head' complex, closed stigma lobes and downwardly directed hairs in corolla tube. D, 1/s of young bud showing flower structure and calycine colleter (Tilney 267); E, l/s of bud just prior to opening showing rare condition where style is looped such that stigma is near corolla throat (Thompson s.n.). F, G, Tilney 267: F, t/s of bud showing relationship between pollen sacs and furrows of 'stylar head' complex and large number of cells with tanniniferous deposits on dorsal face of anthers; G, 1/s of portion of corolla lobe showing 'unzipping' appearance where epidermal cells have elongated and formed thickened outer cell walls and cuticle. $\mathrm{H}, \mathrm{t} / \mathrm{s}$ of portion of corolla lobe showing how epidermal cells interlock at position where corolla lobes of bud will separate and open (Burrows 5998). Scale bars: A, 2 mm; B, $200 \mu \mathrm{m} ; \mathrm{C}, \mathrm{E}, 1$ $\mathrm{mm} ; \mathrm{D}, \mathrm{F}, 700 \mu \mathrm{m} ; \mathrm{G}, \mathrm{H}, 70 \mu \mathrm{m}$.

Common names: rankklipels, rankbokdrol (Afrikaans); climbing turkeyberry, climbing keetia, climbing canthium, monkeyberry (English); mudanhashoko, mudanhanashoko, umhlalalelingonyama (Ndau); mokhutswane (Northern Sotho); ugcupe, sinwati (Swazi), muthambeni (Venda); umnyushulube (Xhosa); ibinda, ugupe, umnyisi (Zulu).
Diagnostic features: in southern Africa this species has ginger-brown trichomes on the young plant parts, and also on the midrib and smaller veins on the abaxial sides of mature leaves, and petioles, pedicels and calyx lobes. The leaves are oblong-lanceolate to ovate with usually subcordate to cordate bases. The lamina is fre- 

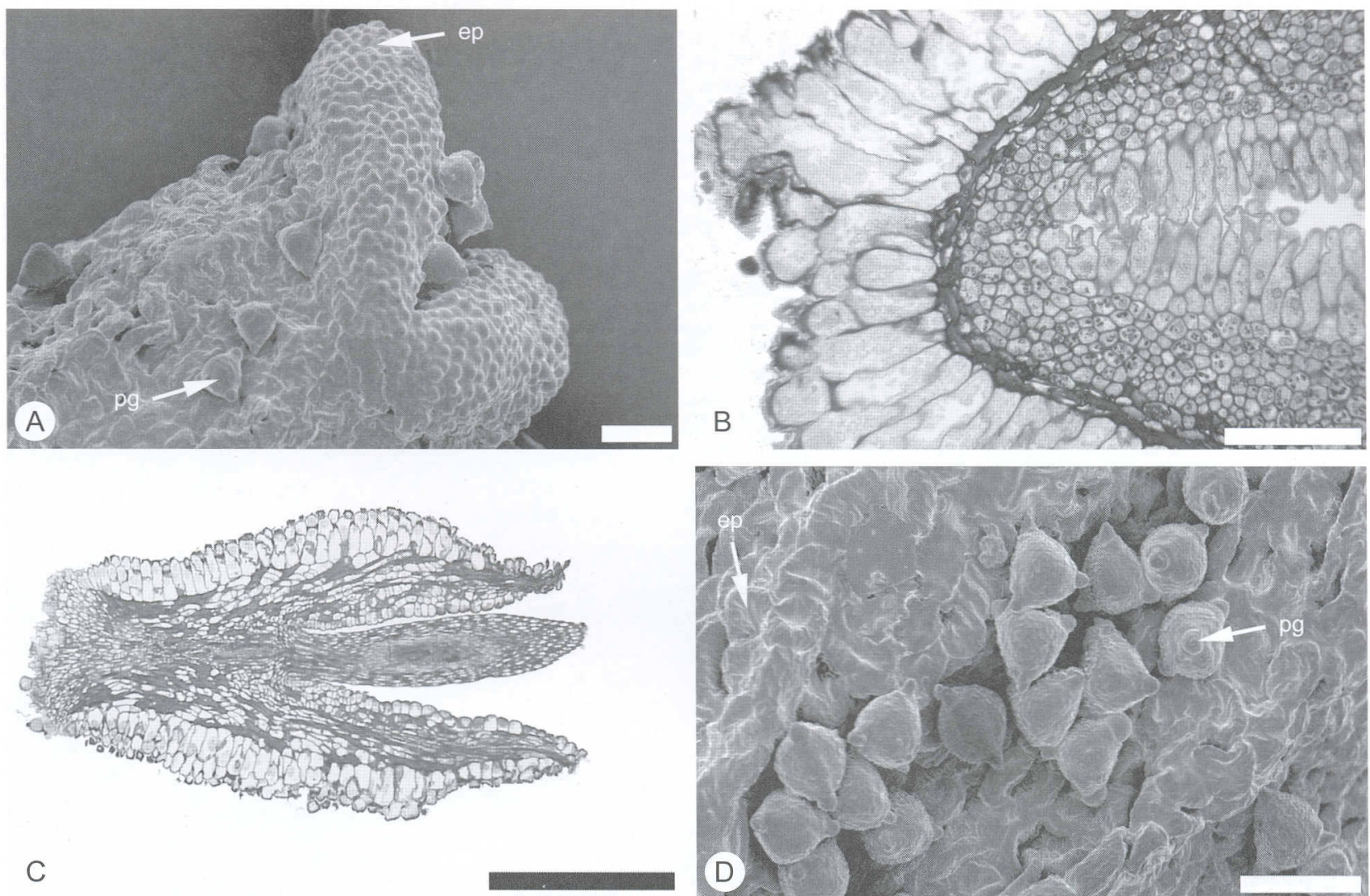

C

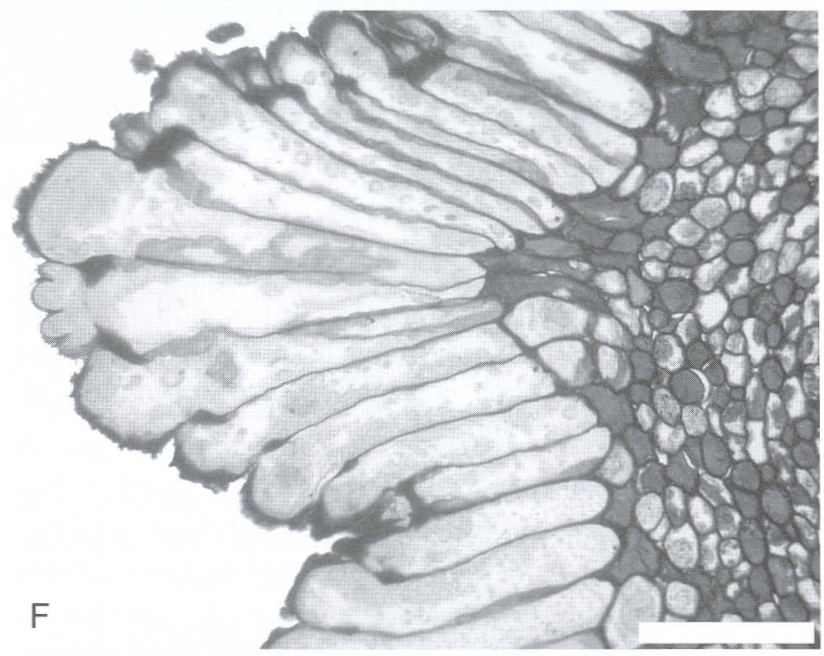

$\mathrm{E}$

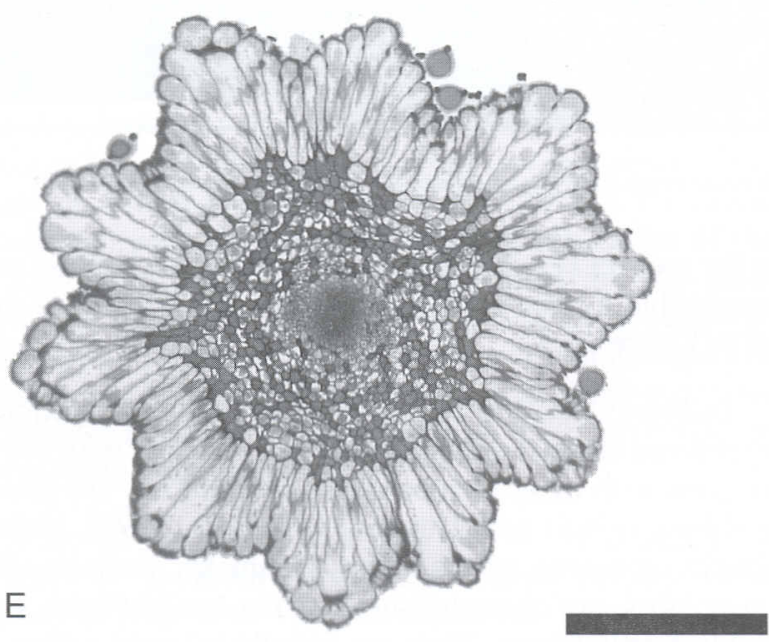

FIGURE 4.-Keetia gueinzii, Thompson s.n.: secondary pollen presentation. A, SEM micrograph of upper portion of 'stylar head' complex with two stigmatic lobes; B, t/s of 'stylar head' complex in region of stigma; C, 1/s of 'stylar head' complex into which style is recessed; D, SEM micrograph of portion of 'stylar head' complex showing lobed epidermal cells and pollen grains in groove; E, t/s of 'stylar head' complex illustrating ten ridges and grooves, with cells forming ridges being much longer than those of grooves, and numerous tanniniferous subepidermal cells; F, t/s of portion of 'stylar head' complex showing elongated epidermal cells with dense cytoplasm, circular thickenings in more distal parts, and thicker cuticle over ridges than in grooves. ep, epidermal cells; pg, pollen grains. Scale bars: A, D, $50 \mu \mathrm{m}$; B, F, $100 \mu \mathrm{m}$; C, $700 \mu \mathrm{m}$; E, $400 \mu \mathrm{m}$.

quently at least $70 \mathrm{~mm}$ long, being glossy and glabrous adaxially. Stipules are conspicuous, lanceolate to ovate and sharply pointed. Hair-tuft domatia (Figure 1A, B) are associated with the axils of most major secondary veins.

Pollination syndrome: although secondary pollen presentation is a rather common phenomenon in the Rubiaceae, the presentation of pollen by a 'stylar head' complex (Igersheim 1993) to a pollinator is a unique characteristic of the tribe Vanguerieae (Lantz et al. 2002). Skottsberg in 1945 described the general anatomy of this 'style-head'. The structure consists not only of stylar tissue but also of the stigmatic lobes and forms a swollen globose to cylindrical structure at the apex of the style into which the style is recessed (Figures 3A; 4C). In buds of Keetia gueinzii, the 'stylar head' complex forms ridges which fit into grooves between the two thecae of each anther and between adjacent anthers; there are thus ten ridges and ten grooves (Figure 3F). Just prior to the bud opening, the style elongates considerably, even rarely forming a loop so that the stigmatic surfaces are in close proximity to the corolla throat (Fig- 


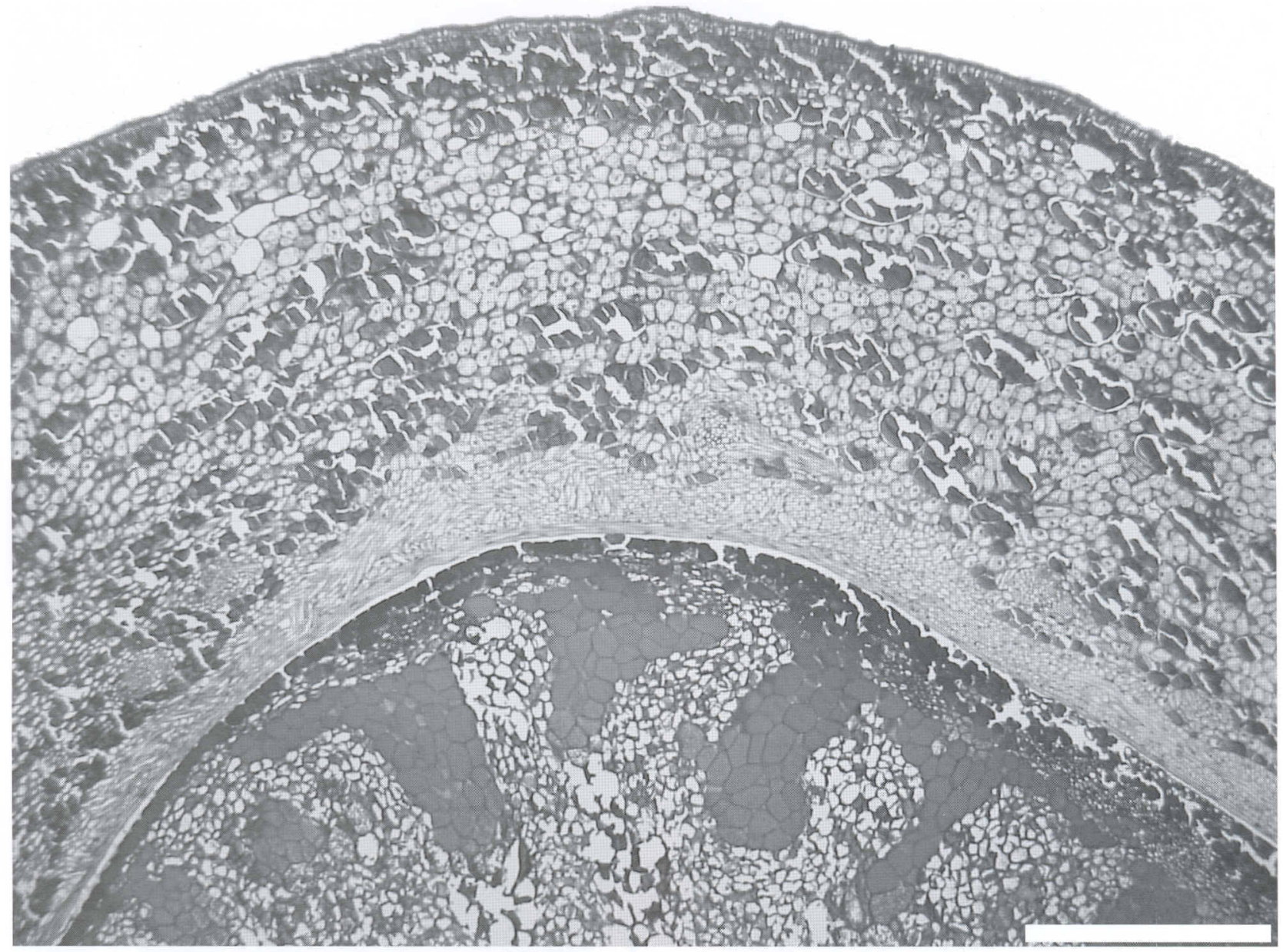

FIGURE 5.-Keetia gueinzii, Kok 712. Portion of pericarp and seed with endosperm showing tanniniferous intrusions. Scale bar: 400 um.

ure 3E). The style and 'stylar head' complex is pale to bright green, the latter covered by yellow pollen. Floral structure suggests pollination by night-flying moths, but this needs confirmation, especially since pollination by beetles has also been suggested.

The 'stylar head' complex of Keetia gueinzii was studied using light (in $\mathrm{t} / \mathrm{s}$ and $1 / \mathrm{s}$ sections) and scanning electron microscopy (Figures $3 ; 4$ ). The anatomy of this structure in $K$. gueinzii resembles that of $K$. zanzibarica (Klotzsch) Bridson subsp. zanzibarica and three species of Vangueria (Igersheim 1993) in the unusual elongated epidermal cells of the 'receptaculum pollinis' with circular thickenings towards the outer tangential walls, abundant tanniniferous cells and conspicuous transmitting tissue in the style (Figure 3F; 4E). However, the lobed nature of the outer tangential portions of many of the elongated epidermal cells (Figure 4D, F) is a conspicuous feature not commented on previously, but visible in published photographs of longitudinal sections of $K$. zanzibarica subsp. zanzibarica (Igersheim 1993). In K. gueinzii, these elongated epidermal cells are densely cytoplasmic, especially distally, and droplet-like structures were frequently observed (Figure $4 \mathrm{~F}$ ). These cells are likely to produce a secretion to enable pollen grains to adhere to them. Sections were tested with Sudan black and Sudan 111 and the outer walls were found to be cutinized. A thicker cuticle was observed over the ridges than in the grooves. In transverse section, it can be seen that those cells forming the longitudinal ridges of the 'stylar head' complex are longer than those in the grooves (Figure 4E, F). The circular thickenings are responsible for the bicellular appearance of many of the cells (Figure 4E, F).

Anatomy: detailed descriptions of the leaf (petiole, midrib and lamina) and stem anatomy, together with comparisons with other members of Canthium s.l., are given in Tilney (1986) and Tilney et al. (1988, 1990). Hairs, present on leaves, young stems, peduncles, pedicels and calyx lobes, are characteristically long, multicellular and highly tanniniferous. They are usually inserted within a raised cluster of small epidermal cells. Hair-tuft domatia in which these hairs extend into the cavity of the domatium are shown in transverse section (Figure 1B). Different species of mites, of which one is shown in Figure 1A, were readily observed associated with them. In the petiole and midrib, the main vascular bundle is a distinctive arc with invaginated ends (Figure 1B). The first-formed periderm in stems originates cortically and in segments. Wood anatomy of some species, including Keetia cornelia (Cham. \& Schltdl.) Bridson, K. cf. gueinzii (Sond.) Bridson and $K$. cf. hispida (Benth.) Bridson, is covered by Lens et al. (2000). All the features of the wood anatomy of these three taxa correspond with those of other members of the tribe Vanguerieae. The secondary xylem has been found to be homogeneous in this tribe.

Intercellular spaces in the mesophyll of healthy mature leaves may contain abundant non-nodulating, slime-producing bacteria (Figure 2F), here reported in 
a member of Keetia for the first time. Hitherto this particular form of bacterial symbiosis was known only in the rubiaceous genera Pachystigma Hochst. and Fadogia Schweinf. (Van Wyk et al. 1990), both belonging to the Vanguerieae. The presence of these seemingly nonpathological bacteria, the functional significance of which remains a mystery, is easily overlooked in anatomical studies and their presence should be checked in other Rubiaceae.

Colleters are present, usually singly or in pairs (the so-called 'alternate' pattern of Simões et al. 2006), on the adaxial surface of the calyx usually between the calyx lobes (Figures 2C-E; 3B, D). They form as emergentia from the calyx lobes (Figure 2E). The main body (termed a 'head' by Thomas 1991) is undivided and is attached by means of a short stalk. Colleters are of the 'standard' type of Lersten (1974a, b), being composed of columnar epidermal cells not separated from each other and having a central parenchymatous axis. Epidermal cells have dark-staining materials adjacent to the cell walls (Figure 2C). During maturation of the colleters, the epidermal cells become more densely cytoplasmic and columnar. Colleters were not observed on the stipules. These secretory structures occur in a large number of rubiaceous species where they are usually associated with the stipules. They are believed to protect the developing shoot apex although other functions have been ascribed to them (e.g. Klein et al. 2004).

As mentioned above, valvate aestivation of the corolla lobes is a character of the tribe Vanguerieae. Furthermore, the margins of the lobes are thickened and usually thicker towards the apex. During development of the buds of Keetia gueinzii it was observed that the future epidermal cells, in the position where separation of the corolla lobes will take place at anthesis, initially elongate and interlock (Figure $3 \mathrm{G}, \mathrm{H}$ ). The outer periclinal cell walls of these cells gradually become thickened and striate, and a cuticle is deposited. Both these processes appear to facilitate the separation of the cells giving an 'unzipping' appearance.

Palynology: pollen is a pale yellow. SEM and TEM studies of southern African specimens (Tilney 1986; Tilney \& Van Wyk 1997) revealed the following taxonomically significant characteristics of the pollen grains: a length (P) of (36-)40-45 $\mu \mathrm{m}$, diameter (E) of 40-50 $\mu \mathrm{m}$, suboblate to spheroidal shape, circular apertures, coarsely reticulate exine $2.6-4.2 \mu \mathrm{m}$ thick with a sexine: nexine ( $\mathrm{S}: \mathrm{N}$ ) of $\mathrm{S}= \pm 2 \mathrm{x} \mathrm{N}$, tectum thickness of $0.6-0.8$ $\mu \mathrm{m}$, nexine thickness of $0.5-1.2 \mu \mathrm{m}$, and the columellae $2 \mu \mathrm{m}$ in height. Lens et al. (2000) also noted that the margin of the ecto-aperture is not obviously demarcated, and is circular, the sexine semitectate, the lumina elongated, the columellae long $( \pm 2.7 \mu \mathrm{m})$ and widely separated. Apertures of fresh grains have prominent protruding onci-or so-called 'pollen buds' of some authors (Tilney \& Van Wyk 1997; Dessein et al. 2005).

Distribution and habitat: occurs in Limpopo, Mpumalanga, Swaziland, KwaZulu-Natal and Eastern Cape (Figure 6), also northwards in Africa to Cameroon and Ethiopia. With Keetia venosa, it shares the distinction of being one of the most widespread species of Keetia in Africa. It is often locally common, occurring at the

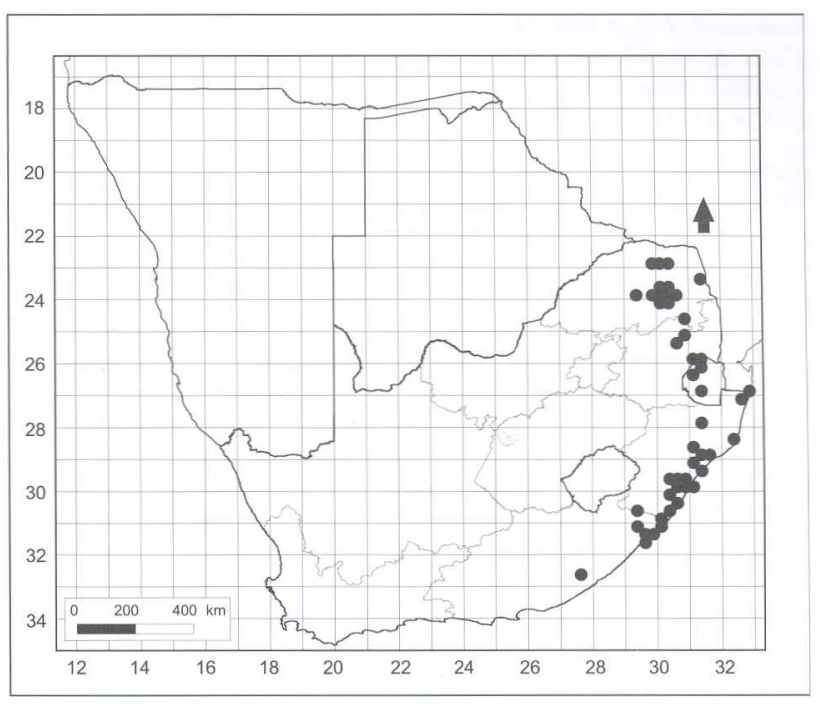

FIGURE 6.-Known distribution of Keetia gueinzii in the Flora of southern Africa region. Arrow indicates that its distribution extends further north into tropical Africa.

margins of and in evergreen forest and thickets, and in swamp forest.

Ecological significance and ethnobotany: used as knob-sticks in Swaziland (Dlamini 1981). Fruits are edible but astringent (Coates Palgrave 2002) and specifically eaten by the Luvale people (Watt \& BreyerBrandwijk 1962). Peters et al. (1992) also quote reports of fruits being eaten by baboons and chimpanzees as well as leaves and cambium by the latter. The Luvale use this species medicinally but no details are available (Watt \& Breyer-Brandwijk 1962). The Swazi use the root medicinally (Dlamini 1981). Neuwinger (2000) refers to authors reporting that the leaves are pounded in a little water and the liquid drunk for epilepsy. Also, for hydrocele, a leaf infusion is drunk and used as a wash and, for colic, abdominal pain and nausea especially during pregnancy, and intestinal parasites, a leaf decoction is drunk. An extract of Keetia hispida (Benth.) Bridson has shown strong activity against Gram + ve bacteria (Koné et al. 2004).

A population heavily infested with galls has been recorded and a portion of a leaf showing these structures macroscopically and in transverse section is shown in Figure 1C, D respectively. In southern Africa the following ascomycete fungal pathogens have been recorded on Keetia gueinzii (Doidge 1950): Balladyna tenuis Hansf., B. velutina (Berk. \& M.A.Curtis) Höhn., Balladynocallia glabra (Hansf.) Bat. (= Balladynastrum glabrum Hansf.) (all Parodiopsidaceae) and Meliola littoralis Syd. (Meliolaceae).

\section{SPECIMENS EXAMINED (FSA region only)}

Abbott 70 PRE, PRU; 3799, FSA?7251 PRU. Acocks 10957, 11805 PRE.

Balkwill \& Cadman 2016 PRE. Barnard \& Mogg 17424 PRE. Borchards 55 PRE. Botha 2949, 3470, s.n. herb. No. 607I PRE. Bower 9212 PRE. Brand, Bosch, Logie, Venter 342 PRE. Bredenkamp 1369 PRE, PRU. Buthelezi 301, 619 PRE. 
Canson \& Irvine 95B PRE. Cloete 1913, 2085 NH. Codd 3056 PRE. Codd \& De Winter 3087 PRE. Codd \& Dyer 4516 PRE. Coleman 406 NH. Compton 2873d, 24756, 28200 NBG; 28218, 29120, 29476, 30658, 31551,31719 NBG, PRE; 28734 PRE. Cooper 80 PRE.

Davis 86 NH. De Winter 8255 PRE. De Winter \& Vahrmeijer 8599 PRE. Dlamini s.n. PRE; s.n. NH; 38301, 43743, 49529, 57029 NBG. Doidge 6070 PRE.

Eastwood 1284 PRE. Edwards 1308, 1381 PRE. Elan-Puttick 94, 142 PRE.

Felton \& Thornhill FSA347 PRU. Fitzsimons \& Dam 26276 PRE

Galpin 519, 9397 PRE. Gerstner 4507, 5412 PRE; s.n. NH. Gordon $352 \mathrm{NH}$.

Hafström \& Acocks 1929 PRE. Hahn FSA327, 386 PRU. Heath 294, 518 PRE. Hemm 45, 45 A PRE, PRU. Hobson 2054 PRE. Hutchings $3084 \mathrm{NH}$.

Jacobsen 5305 PRE. Jordaan 3120 PRE. Junod 4152 PRE.

Keet 1181, 1335 PRE; US15255 NBG. Kemp 1116 PRE. Kirkman 3057 PRE. Kluge 25, 1585 PRE. Korsten s.n. PRE. Krige 136 PRE.

Law 70 NBG. Lawn s.n., 170 NH. Leighton 2982 PRE. Leistner, Thom \& Gillham 3282 PRE. Lubke FSA262 PRU, NH.

MacDevette 1542 PRE. Marloth 4095 PRE. McCallum s.n., 708 PRE. Meeuse 9394 PRE. Miller 8497, S/151 PRE. Mills 394 PRE. Moffet 1480 PRE. Mogg \& Nicholson 37974 PRE. Moll 2196, 2298, 2722 PRE.

Nel 350 PRE, NBG. Nicholson 102 NH.

Obermeyer 859 PRE; TM30111.

Pegler 2002 SAM. Plath s.n. PRE. Pole-Evans 3750 PRE. Pott TM13528. Poynton \& Brent For. Herb. 11601. Prior 390 PRE.

Rael 541 PRE. Rodin 4102 PRE. Rogers TMI3870, TM18904, TM24016?, TM24426?

Sanderson 846 NH. Scheepers 362 PRE, PRU; 813 PRE. Scheepers \& Haasbroek s.n. PRE. Schlechter 12290 SAM. Schmidt 28 NH. Sidey 3004 PRE. Sim s.n., 20215, 2392 PRE; 2393 SAM. Skott 1661 PRE. Smook 1267 PRE. Smuts \& Gillett 3184 PRE. Stalmans 264, 593, 1117 PRE. Strey 6881 PRE, NH; 7152, 8510 PRE. Swynnerton 49 NH; 170 SAM, PRE.

Thorncroft 372 PRE; 898 NH. Tilney 156, 162 JRAU, PRE, PRU.

Vahrmeijer 510, 1476 PRE. Vahrmeijer \& Tölken 927 PRE. Van der Schiiff 4373, 4560, 6168 PRE, PRU; 4792 PRU. Van Jaarsveld 519 NBG, PRE. Van Jaarsveld, Van der Walt \& Crous 32 PRE. P.van Wvk BSA349, BSA616 PRU. P.van Wyk \& Hahn BSA838 PRU. Van Wyk 1640 PRE; FSA 10424, FSA12215 PRU; 2174, 2702, 2966 PRE, PRU. Van Wyk \& Kok 5888 PRE, PRU. Van Wyk \& Theron 4568, 4569, 4872 PRE, PRU. Venter 89, 1858, 12661 PRE; 272, 438 NH. Victoria College (Stellenbosch) Herbarium US15254 NBG.

Wager 23009 PRE. Ward 1086, CJ1525, CJ5243, CJ9888 PRE; 1647, MC1549 NH. Wells \& Edwards 28 PRE. Wood s.n., 10378, 11392, 12773 PRE; ?3853 PRU; 305, 11356 NH; 5477 PRE, SAM. Whyte Herb. Musei Austro-Africani 16033 SAM. Wylie $8550 \mathrm{NH}$.

\section{ACKNOWLEDGEMENTS}

We would like to thank the curators and staff of the following herbaria for making their material available to us for study: NBG, NH, PRE and SAM. We are also very grateful to Mr A.R. Magee and Ms H.M. Steyn for their help with the figures. We thank two anonymous referees for their enriching comments and suggestions.

\section{REFERENCES}

BEWS, J.W. 1921. An introduction to the flora of Natal and Zululand. City Printing Works, Pietermaritzburg.

BRIDSON, D.M. 1985. The reinstatement of Psydrax (Rubiaceae, subfam. Cinchonoideae tribe Vanguerieae) and a revision of the African species. Kew Bulletin 40: 687-725.
BRIDSON, D.M. 1986. The reinstatement of the African genus Keetia (Rubiaceae subfam. Cinchonoideae, tribe Vanguerieae). Kew Bulletin 41: 965-994.

BRIDSON, D.M. 1987. Studies in African Rubiaceae-Vanguerieae: new circumscription of Pyrostria and a new subgenus, Canthium subgen. Bullockia. Kew Bulletin 42: 611-639.

BRIDSON, D.M. 1991. Rubiaceae. In Flora of tropical East Africa: 911, figs. 131/16, 25; 132/25, 162 .

BRIDSON, D.M. 1992. The genus Canthium (Rubiaceae-Vanguerieae) in tropical Africa. Kew Bulletin 47: 353-401.

BRIDSON, D.M. 1998. Rubiaceae (tribe Vanguerieae). In G.V. Pope, Flora zambesiaca 5,2: 211-377. Royal Botanic Gardens, Kew, London.

BULLOCK, A.A. 1932a. Canthium gueinzii. Hooker's Icones Plantarum: t. 3170 . London.

BULLOCK, A.A. 1932b. Canthium in British East Africa. Kew Bulletin 1932: 353-389.

COATES PALGRAVE, K. 1977. Trees of southern Africa. Struik, Cape Town.

COATES PALGRAVE, M. 2002. Keith Coates Palgrave Trees of southern Africa, edn 3. Struik, Cape Town.

COMPTON, R.H. 1976. The flora of Swaziland, Suppl. vol. 11. National Botanic Gardens of South Africa, Cape Town.

DALE, I.R. \& GREENWAY, P.J. 1961. Kenya trees and shrubs. Buchanan's Kenya Estates, Nairobi \& Hatchards, London.

DESSEIN, S., OCHOTERENA, H., DE BLOCK, P., LENS, F., ROBBRECHT, E., SCHOLS, P., SMETS, E., VINCKIER, S. \& HUYSMANS, S. 2005. Palynology characters and their phylogenetic signal in Rubiaceae. The Botanical Review 71: $354-414$.

DLAMINI, B. 1981. Swaziland flora: their local names and uses. Ministry of Agriculture and Co-operatives: Forestry Section, Mbabane.

DOIDGE, E.M. 1950. The South African fungi and lichens to the end of 1945. Bothalia 5: 1-1094.

DYER, R.A. 1975. The genera of southern African flowering plants. I Dicotyledons. Botanical Research Institute, Pretoria.

EYLES, F. 1916. A record of plants collected in Southern Rhodesia Transactions of the Royal Society of South Africa 5: 273-564.

FEDER, N. \& O' BRIEN, T.P. 1968. Plant microtechnique: some principles and new methods. American Journal of Botany 55 123-142.

GIBSON, J.M. 1975. Wild flowers of Natal (coastal region). The Trustees of the Natal Publishing Trust Fund, Durban

GUNN, M. \& CODD, L.E. 1981. Botanical exploration of southern Africa. Balkema, Cape Town.

HEDGE, T. 1993. Tribute to an amateur: Wilhelm Gueinzius-naturalist sui generis. PlantLife 8: 10-13

HENKEL, J.S. 1934. The woody plants of Natal and Zululand. Natal University Development Fund Committee, Durban \& Pietermaritzburg.

HEPPER, F.N. 1963. Canthium. In F.N. Hepper, Flora of West tropical Africa, edn 2, 2: 180-185. Crown Agents for Oversea Governments and Administrations, London.

HIERN, W.P. 1877. Canthium. In D. Oliver, Flora of tropical Africa 3: 132-146. Reeve, London.

HOLMGREN, P.K., HOLMGREN, N.H. \& BARNETT, L.C. 1990. Index Herbariorum 1: The Herbaria of the World. Regnum Vegetabile, edn 8. New York Botanical Garden, New York.

IGERSHEIM, A.F. 1993. Gynoecium development in Rubiaceae-Vanguerieae, with particular reference to the 'stylar-head'-complex and secondary pollen presentation. Plant Systematics and Evolu tion 187: 175-190.

KLEIN, D.E., GOMES, V.M., DA SILVA-NETO, S.J. \& DA CUNHA, M. 2004. The structure of colleters in several species of Simira (Rubiaceae). Annals of Botany 94: 733-740.

KONÉ, W.M., ATINDEHOU, K.K., TERREAUX, C., HOSTETTMANN, K., TRAORE, D. \& DOSSO, M. 2004. Traditional medicine in north Cote-d'Ivoire: screening of 50 medicinal plants for antibacterial activity. Journal of Ethnopharmacology 93,1: 43-49.

LANTZ, H., ANDREASEN, K. \& BREMER, B. 2002. Nuclear rDNA ITS data used to construct the first phylogeny of Vanguerieae (Rubiaceae). Plant Systematics and Evolution 230: 173-187.

LANTZ, H. \& BREMER, B. 2004. Phylogeny inferred from morphology and DNA data: characterizing well-supported groups in Vanguerieae (Rubiaceae). Botanical Journal of the Linnean Society 146: 257-283.

LENS, F., JANSEN, S., HUYSMANS, S., ROBBRECHT, E. \& SMETS, E. 2000. Wood anatomy of the Vanguerieae (Ixoroideae-Rubiaceae), with special emphasis on some geofrutices. IAWA Journal 21: $443-455$. 
LERSTEN, N.R. 1974a. Morphology and distribution of colleters and crystals in relation to the bacterial leaf nodules in Psychotria (Rubiaceae). American Journal of Botany 61: 973-981.

LERSTEN, N.R. 1974b. Colleter morphology in Pavetta, Neorosea and Tricalysia (Rubiaceae) and its relationship to the bacterial leaf nodule symbiosis. Botanical Journal of the Linnean Society 69: $125-136$.

MOORE, S. 1911. A contribution to our knowledge of the flora of Gazaland. Journal of the Linnean Society (Botany) 40: 87-91.

NEUWINGER, H.D. 2000. African traditional medicine. A dictionary of plant use and applications. Medpharm Scientific Publishers, Stuttgart.

PALMER, E. \& PITMAN, N. 1972. Trees of southern Africa, vols 1, 2 and 3. Balkema, Cape Town.

PETERS, C.R., O'BRIEN, E.M. \& DRUMMOND, R.B. 1992. Edible wild plants of sub-Saharan Africa. Royal Botanic Gardens, Kew.

PHILLIPS, E.P. 1926. The genera of South African flowering plants, edn 1. Memoirs of the Botanical Survey of South Africa No. 10.

PHILLIPS, E.P. 1927. Description of three new South African plants. Bothalia 2: $368,369$.

PHILLIPS, E.P. 1951. The genera of South African flowering plants, edn 2. Memoirs of the Botanical Survey of South Africa No. 25.

POOLEY, E. 1993. The complete field guide to trees of Natal, Zululand and Transkei. Natal Flora Publications Trust, Durban.

RETIEF, E. \& LEISTNER, O.A. 2000. Rubiaceae. In O.A. Leistner, Seed plants of southern Africa: families and genera. Strelitzia 10: 476-495. National Botanical Institute, Pretoria.

SCHMIDT, E., LÖTTER, M. \& McCLELAND, W. 2002. Trees and shrubs of Mpumalanga and Kruger National Park. Jacana, Johannesburg.

SIM, T.R. 1907. The forests and forest flora of the Colony of the Cape of Good Hope. Taylor \& Henderson, Aberdeen.

SIMÕES, A.O., DE M.CASTRO, M. \& KINOSHITA, L.S. 2006. Calycine colleters of seven species of Apocynaceae (Apocynoideae) from Brazil. Botanical Journal of the Linnean Society 152: 387-398.

SKOTTSBERG, C. 1945. The flower of Canthium. Arkiv för Botanik 32A, $5: 1-12$

SONDER, W. [O.W.] 1850. Beiträge zur Flora von Südafrica. Linnaea 23: $1-138$
SONDER, W. [O.W.] 1865. Rubiaceae. In W.H. Harvey. \& O.W. Sonder, Flora capensis 3: 1-39. Hodges, Smith, Dublin.

THOMAS, V. 1991. Structural, functional and phylogenetic aspects of the colleter. Annals of Botany 68: 287-305.

TILNEY, P.M. 1986. The taxonomic significance of anatomical and morphological characters in the southern African species of Canthium Lam., (Rubiaceae). Ph.D. thesis, University of Pretoria.

TILNEY, P.M. 2002. Canthium, Keetia and Psydrax (Rubiaceae) in South Africa. Part 1: notes and simple field key. PlantLife 27: $37-40$.

TILNEY, P.M. 2003a. Canthium, Keetia and Psydrax (Rubiaceae) in South Africa. Part 2: how to recognize the South African species of Canthium. PlantLife 28: 19-25.

TILNEY, P.M. 2003b. Canthium, Keetia and Psydrax (Rubiaceae) in South Africa. Part 3: how to recognize the South African species of Keetia and Psydrax. PlantLife 29: 28-32.

TILNEY, P.M. \& VAN WYK, A.E. 1997. Pollen morphology of Canthium, Keetia and Psydrax (Rubiaceae: Vanguerieae) in southern Africa. Grana 36: 249-260.

TILNEY, P.M., VAN WYK, A.E. \& KOK, P.D.F. 1988. The taxonomic significance of anatomical characters of the stem in the southern African species of Canthium s.l. (Rubiaceae). South African Journal of Botany 54: 585-595.

TILNEY, P.M., VAN WYK, A.E. \& KOK, P.D.F. 1990. The taxonomic significance of anatomical characters of the leaf in the southern African species of Canthium s.l. (Rubiaceae). South African Journal of Botany $56: 363-382$.

VAN WYK, A.E., KOK, P.D.F., VAN BERS, N.L. \& VAN DER MERWE, C.F. 1990. Nonpathological bacterial symbiosis in Pachystigma and Fadogia (Rubiaceae): its evolutionary significance and possible involvement in the aetiology of gousiekte in domestic ruminants. South African Journal of Science 86: 93-96.

VAN WYK, A.E. [Braam] \& VAN WYK, P. 1997. Field guide to trees of southern Africa. Struik, Cape Town.

VON BREITENBACH, F. 1985. Canthium-Psydrax-Keetia? Journal of Dendrology 5: 79-93.

WATT, J.M. \& BREYER-BRANDWIJK, M.G. 1962. The medicinal and poisonous plants of southern and eastern Africa. Livingstone, Edinburgh and London.

WHITE, F. 1962. Forest flora of Northern Rhodesia. Oxford University Press, Oxford. 